\title{
Art and Its History ${ }^{1}$
}

\author{
Risto Pitkänen
}

\begin{abstract}
AвSTRACт The paper argues that something is art only if (i) it belongs to a special kind of internal history and (ii) needs to be understood and appreciated in the light of such history. This goes against both the traditional view that art has a timeless, ahistorical essence and the historicist view that there can be no ahistorical perspective for understanding art. The paper draws on Hegel's view that art needs to be understood through its history, but rejects the idea that the history of art has an end in the double sense of a goal and an end point. It also rejects Arthur Danto's Hegel-inspired claim that the ahistorical essence of art is revealed at the end of its history and opens the door to a natural alliance between philosophers of art and art historians.

KEYWORDS History of art, Hegel, philosophy of art
\end{abstract}

Art is in a pretty humdrum sense the sort of thing that necessarily has a history. But from this alone it does not follow that art is essentially historical in the sense that understanding what art is would essentially turn on its historical character. Science and technology also necessarily have a history, but most of us would say that they are not essentially historical. One can say what science and technology are as human enterprises with no substantial reference to their history. Religion is an interesting case, as those looking at religion from the inside would, I think, say that it is essentially ahistorical, while those looking at it from the outside are likely to see it in historical terms.

In aesthetics there is a tradition, running from Plato and Aristotle through Kant to analytical aesthetics, which seeks to identify a timeless and universal nature or essence of art. Then there is the tradition, clustered around Hegel, which seeks to explain the nature or essence of art through or against its history. I shall argue that the truth lies in between. The history of aesthetics is littered with failed attempts to define art ahistorically. On the other hand, the historicist claim that the very idea of any kind of suprahistorical perspective on art makes no sense reduces aesthetics to cultural philosophy musing on the diversity of different ages and cultures, or speculating on what options there may be open to contemporary or future art. Hegel was not a historicist in this sense. ${ }^{2}$ But neither was he an ahistorical universalist in the manner of Kant, whose account of art makes no substantive reference to history. ${ }^{3}$ Hegel says that by his time art has reached the stage of historical development where it "invites us to intellectual consideration [...] for knowing scientifically ${ }^{4}$ 
what art is." It is possible to read this as saying that history is for Hegel like the ladder of philosophy for Wittgenstein and can be thrown away once you have climbed to the top of it. ${ }^{6}$ This is the interpretation the greatest contemporary champion of Hegel's aesthetics, Arthur Danto, puts on Hegel. Danto argues that art reveals its own nature or essence at the end of its history and is thereby liberated from that history. I think this is not the best way of understanding Hegel. As I read Hegel, he is not saying that the supposed end of (the history of) art transforms art into something essentially ahistorical, which is the crux of Danto's strategy for rescuing art from Hegel's conclusion that art had become a spent cultural force. I shall argue that it is the notion of an end of history that misleads both Hegel and Danto. If we can explain the historicity of art with no reference to ends of history, as I am convinced we can, then we need not accept Hegel's conclusion that art is a thing of the past, nor Danto's quixotic claim that art has turned into philosophy. Hegel is unduly pessimistic, while the ahistorical essence that Danto ascribed to art makes sense only against the history of art.

Hegel and Danto think that we can come to understand the essence of art through understanding its history. In my view we can come to understand the historicity of art through coming to understand the history of art. This may sound like a trivial and circular enterprise, but I hope to show that dovetailing history and historicity is not a circular undertaking if, in addition to philosophical reflection, it assigns a proper role for historical discovery.

I believe a firmer grasp of the historicity of art will also enable aesthetics to see more clearly what common ground it may have with the scholarly study of art, while at the same time taking distance to art theory, at least in its more historicist reaches. As I see it, the future of aesthetics as an independent field of inquiry largely depends on its independence in relation to the scholarly study of art on the one hand and to art theory on the other hand. ${ }^{7}$ That is too large a question, though, to be properly tackled here and I shall not go into it, save a few general remarks towards the end of this paper.

\section{The historical particularity of art}

The observation that, like such other human enterprises as science, technology and religion (looked at from the outside), ${ }^{8}$ art necessarily has a history obviously does not entail that art necessarily has the history - or rather, histories - it has. Hegel thought that in addition to necessarily having a history, art also necessarily had the type of history it had, but 
that is a different thing. Hegel thought that art could, as it were, come to the world only through a certain type of historical and cultural development, but the actual shape and content of that history were not predetermined by some Platonic idea of art nor der Geist, the Spirit, to whose developmental history art belongs in Hegel's philosophy. The direction is given at the outset, but the actual historical development is contingent for the simple and sound reason that the actual circumstances of history and culture are always contingent. On no reasonable reading can Hegel be accused (or praised) of historical determinism. ${ }^{9}$

The idealistic trappings of Hegel's aesthetics are, as Danto says, "[b]izarre [...] in every possible respect." ${ }^{10}$ But what is of enduring value and interest in Hegel can, as Danto has demonstrated, be re-formulated and thought about with no commitment to the underlying idealistic metaphysics. ${ }^{11}$ And it is a worthwhile enterprise, as Hegel shows more insight into the historicity of art than any other major philosopher of art.

Hegel was well aware that the grand philosophical history of art that he delineates in his vast Vorlesungen über die Ästhetic (Lectures on Fine $A r t$, as it is known in English ${ }^{12}$ ) glosses over countless factual histories (Realgeschichten, as Hegel would have called them). In his discussion of existing "scientific ways of treating art," Hegel distinguishes the philosophical enterprise from (art) scholarship (Kunstgelehrsamkeit), which has its starting point in the empirical. ${ }^{13}$ He states in passing the idea that continues to dominate art history:

[...] every work of art belongs to its own time, its own people, its own environment, and depends on particular historical and other ideas and purposes $[. . .]^{14}$

Eighty years after the first publication of Hegel's edited lecture notes, Heinrich Wölfflin, one of the founders of modern art history, states the guiding principle of the budding branch as a self-evident truth with the slogan "Different times give birth to different art." According to Wölfflin, the natural working practice of art history is then "to draw parallels between periods of culture and periods of style."15

In Hegel's view the scholarly study of art that later became known as art history is of enduring value, but is at the same time of necessity too wedded to the historical particularities of art to be able to establish the true nature of art. ${ }^{16}$ (It is noteworthy that in the philosophical introduction of Aesthetics Hegel discusses art virtually exclusively in terms of the visual arts. Hegel's influence is evident in the predominance of the visual arts in later aesthetics. This would be an interesting topic for historians of aesthetics.) Here it may be in order to stress that although Hegel does 
occasionally speak of the Zeitgeist (the spirit of the time), ${ }^{17}$ which is commonly thought to explain the historical fit between art and culture at large, the vague blanket notion has no place in his more rigorous philosophical thinking. ${ }^{18}$

Traditional philosophical theories of art, such as Aristotle's Poetics, constitute another approach to the "primarily historical treatment" of art. In Hegel's view, the philosophical shortcoming of these kinds of art theories is that "in their generality (Allgemeinheit) they make no progress towards establishing the particular (Besonderes)."19

What Hegel is saying, I think, is that an adequate philosophy of art must be able to account for both the concrete historical particularity and the universal arthood of the individual works of art. That is a very tall order indeed and I doubt that any philosophy of art, including Hegel's own, can rise to meet it. But it should at the very least make us wary of the tendency of philosophers of art to illustrate, support and test their theories by more or less random citing of works of art torn out of their historical context. The thought is presumably that if the theory captures the essence of art, then it can be tested against any work, or, as I would prefer to say, instance of art. ${ }^{20}$ However, such testing becomes circular or is at the very least theory-laden in a vitiating sense if it recognises in the instance only the features it projects into it and ignores others that a contextual description could draw out. I doubt that there is any theory or definition of art that could not be faulted on this score.

In his customary fashion Hegel purports to find the right approach to the "scientific treatment" of art between the extremes of art scholarship as the study of the historical particularities of art and the traditional philosophy of art as purely theoretical reflection. According to Hegel, traditional philosophy of art strives to get to the bottom of the idea of the beautiful as such. ${ }^{21}$ As Hegel thought the core of art was its beauty and the only kind of beauty meriting philosophical inquiry was beauty of art, establishing the essence of beauty of art would ipso facto give the true nature of art. The traditional way of trying to get at the universal essence of beauty and art directly past the particulars of art turns the inquiry into "abstract metaphysics" which no longer satisfies the "richer philosophical needs of our contemporary spirit," Hegel announced in the 1820 s. $^{22}$

The true philosophical concept of the beautiful (and thereby of art) must unite metaphysical universality with the determinateness (Bestimmt$h e i t)^{23}$ of its real particularity. ${ }^{24}$ And that will, in Hegel's view, necessarily involve tracing the history of art. Even if we allow that Hegel obviously had in mind a philosophical history, as distinct from art scholarship's 
account of historical particularities, ${ }^{25}$ the task is truly daunting. However, I believe it is possible to come to grips with the historicity of art on roughly Hegelian lines without trying to out-Hegel Hegel. A closer look at Hegel's massive survey of the history of art reveals that the focus is not on the actual history, but on concepts that can be used to identify the various historical contexts of art. The three "forms" of art (Symbolic, Classical and Romantic) are best seen as broad historical stylistic categories which are then given content through an analysis of the different arts and the various expressive devices (e.g. symbol), genres (e.g. satire), themes (e.g. chivalry) and so on, characteristic of and emerging in the course of this history of styles. The claim made by Hegel's Aesthetics as a whole is that the essential particularity of art can be captured by means of that particular historical framework. Now while the general idea of understanding works of art in their historical contexts is hardly controversial, the claim that there is one right way of determining such contexts most certainly is. And the suggestion that the philosopher of art is competent to identify that historical framework is bound to strike the more sober of us in the profession as a delusion of grandeur. I think Hegel is wrong on the point of there existing some one way of determining the historical particularity of art and I shall argue that the essential historicity of art does not require a unique way of determining the historical particularity of the individual work. From that it does not follow that all attempts to deal with art historically fall foul of relativism. I shall deal with this charge before setting about extricating Hegel's insights from the extravagances of his metaphysics.

\section{Reconciling historical relativism and historical discovery}

From the vantage point of our relativist era, it is all too easy to admit that art history's customary historical framework of periods and styles is not a brute fact waiting for discovery out there, but something imposed by the art historians on the historical contingences of art. Richard Wollheim's argument for that view is most apposite here as it explicitly focuses on art history. Wollheim maintains that art is not essentially historical because the general concepts of style that art history owes to Hegel are of necessity historically relative and cannot therefore capture the essence of the individual style of the artist. General style comes in many forms of historical and cross-historical ${ }^{26}$ styles and in applying a general style concept to an artist's work we are, according to Wollheim, "employing a kind of shorthand for a set of characteristics which we and those who share our outlook find particularly interesting, arresting, innovatory, in 
a stretch of painting. ${ }^{27}$ In other words, general style concepts are historically relative.

However, at different moments, there will be different historical interests, different contemporary concerns, that will make different characteristics seem distinctive of a particular stretch of art and, as this happens, the characteristics associated with general style will alter. ${ }^{28}$

Wollheim contrasts general style with individual style which is the key to the meaning and correct interpretation of an artist's work. The pivotal differences are that the characteristics associated with individual style do not alter and that individual style is not shorthand for some set of characteristics. Instead of reducing style to a shifting set of characteristics, individual style "causes them [the characteristics] to be as they are." Wollheim is saying in effect that individual style has its seat in the mind of the artist and becomes, in the case of painting, visible through the artist's work through which she imbues the material medium with meaning. Wollheim maintains that where general style is just a changeable way of classifying works of art, individual style has genuine explanatory power. Individual style explains how a painting looks the way it does. ${ }^{30}$

What Wollheim is saying in so many words is that there are no enduring truths to be discovered in art history delineated in terms of general styles, while the immutably fixed characteristics associated with an artist's individual style are there waiting to be discovered. If that were so, art would not be essentially historical and the history of art would be reduced to a chronology of (great) artists. (As a historical note, this is the view on history of art most readily suggested by Kant's theory of [fine] art as art of genius. ${ }^{31}$ ) The only essential history would be the history of the development of an artist's individual style. Let us consider Wollheim's view with the help of a concrete example. Vermeer is one of the most enigmatic artists in the history of Western painting. He certainly has an individual style and art historians are still struggling to capture the key to it. Their tools and methods are by and large the same they employ in delineating concepts of general style. Even more important, it is hard to see how we could capture the individual genius of Vermeer without considering him in and against various frameworks of general style - 17th century Dutch interior painting, 17th century Delft painting and so on. If absence of narrative content is one element of Vermeer's style, as has been claimed, this surely becomes apparent when we compare him to contemporary anecdotal painting, represented by for instance Gerard Terborch, or Jan Steen. Wollheim would by no means deny this. 
He would say that distinctions based on concepts of general style can be most relevant to the understanding of the work, but they only constitute part of the cognitive stock ${ }^{32}$ that the viewer brings to her encounter with the work and are no more constitutive of the work itself than say speculations on Vermeer's employment of the camera obscura, or analyses of his painting technique in creating his "optical" approach to painting. ${ }^{33}$

In the end it is a question of how we want to draw the line between what belongs to the work and what belongs to its context, including its historical context. Wollheim wants to lift art out of its history in confining all historical discoveries to the context. As there are no hard facts of art directing us to draw the line between work and its context in any particular way, Wollheim's criticism of (broadly Hegelian) general style does not constitute a compelling refutation of the idea that art is somehow essentially historical. I personally find it very hard to imagine how one could adequately see, say, Vermeer's Woman in Blue Reading a Letter (Rijksmuseum, Amsterdam) without some consciousness of the historical particularity of what there is to see in the painting, and then any adequate "cognitive stock" bearing on the perception will immediately effect a link to the painting's place in the history of not only Vermeer's art but European art at large. Wollheim by no means denies the importance of such linking, but maintains that however much cognitive stock may influence the perception of the work, its role is only to enable us to see the work correctly. ${ }^{34}$

Wollheim wants to exclude history because of the changeability of the categories of what he calls general style. However, his claim that the characteristics associated with individual style are fixed immutably makes the very notion of individual style rather mysterious. According to Wollheim, such style has "psychological reality," that is, it is in some sense hard-wired in the mind (brain) of the artist. ${ }^{35}$ In that case it must be phenotypically a trait that reaches maturity through interaction with the environment, which would be in keeping with the customary way of talking of the development of the artist's style. But the idea of such development being somehow psychologically destined to reach a phase from which on the style manifested in the artist's work is immutably fixed surely re-echoes the Romantic myth of the artist's genius. The only immutability we have to work with is that of the artist's material body of work. I suspect that is the ultimate ground of the alleged immutability of style, but this is not the place to delve deeper into such questions. My point is simply that the undeniable changeability of the (broadly Hegelian) frameworks of general style need not mean that they are arbitrary and only reflect current 
concerns. It seems to me a misunderstanding of the very nature of history to maintain that art can be essentially historical only if there is one true way of accounting for the history of art. Multiplicity and revisability do not render history relative to the point of excluding historical discovery. On the contrary they fire the art historian on to new discoveries.

If Hegel thought his historical scheme was the one true (philosophical) history of art, as he apparently did, he was wrong. We can well say that art is essentially historical and leave it to the historians with their competence for discovery to give content to historicity in individual cases. Aesthetics needs no particular history of art but does need what we could call, in a Hegelian spirit, the idea of such a history. In other words, we need a non-historical analysis of the historicity of art. I now turn to that task.

\section{History without ends}

I shall ask two questions:

(i) How does art have its history?

and

(ii) What type of a history does art have?

Starting with (i), the philosophical fiction of art having just one history here amounts to no more than conjecturing that all histories of art are similar in the relevant respect. It seems to me a reasonable conjecture. I prefer to talk of art having its history to set aside historicism, which says with regard to art that art is irreducibly historical and cannot be understood from a supra-historical perspective. I think that historicism, as practiced for example by Gadamer and Adorno, turns the philosophy of art into philosophical history of culture reflecting the shifting viewpoints and interests of the historians. In other words, it is irreducibly relativist.

To reiterate, Hegel was not a historicist in this sense. However, I think it is an equally mistaken interpretation to take Hegel to say, as Danto for instance does, that the nature or essence of art is ahistorical and it became possible to establish that essence after art had, "in its highest determination ${ }^{36}$ come for us a thing of the past." ${ }^{37}$ Hegel does undoubtedly invite the reading that once the historical development of art has passed its high point and art can no longer find a way of reconciling form and content, as Hegel thought was happening in Romantic art, it becomes possible for the philosopher to take off on the wings of Minerva's owl 
and assume an ahistorical point of view on the nature or essence of art. ${ }^{38}$ I think the correct interpretation is that we can gain through history not an ahistorical but a supra-historical point of view, a point of view in which history is built-in. Hegel's grand scheme of philosophy undoubtedly involves the idea of the end of history, as the end point of development, but surely from such an end point we would not see things ahistorically but rather in their historical fullness. In any case it seems to me that it would be better to think of such an end as an idea enabling us to think of history in a certain way rather than as something we could locate in history.

Hegel's pronouncement about art being a thing of the past has unfortunately given rise to an awful lot of nonsense about the end of art. Arthur Danto did a service to aesthetics when he pointed out that Hegel should be understood as talking not about the end of art but about the end of the history of art as a certain type of history. Hegel makes it abundantly clear that he does not think that art is about to disappear from the world. He certainly thinks that art had become irredeemably inferior art, but that is a judgment on art in relation to its end in the sense of the goal of its development, not in relation to any absolute historical end point. The whole discussion around the alleged end of art tends to suffer from equivocation between the two senses of end as goal and end as end point. Hegel's harsh verdict on his contemporary art surely casts doubt on the idea of there being an end of art in either of the two senses of a goal and an end point of development - unless we are willing to consign all art posterior to "the golden age of the later Middle Ages," 39 to the category of inferior or failed art. Danto tries to rescue both art and Hegel by claiming that in its Hegelian history, art "fulfils its destiny by becoming philosophy at last." ${ }^{40}$ In Danto's version of the history of European art this redeeming transformation happened as late as in the 1960s, a very long time after art had in Hegel's view become a thing of the past. Be that as it may, I cannot find any such destiny for art in Hegel. Art does have the same end as religion and philosophy, that is, reaching (consciousness of) the absolute (idea), but Hegel says very clearly that art and religion cannot, because of their very nature of being wedded to sensuous presentation of ideas, reach that end and their history comes to an end unfulfilled. ${ }^{41}$

Hegel may seem to assert that art has given way to philosophy when he says that art no longer invites us "to thinking reflection with the purpose of calling forth anew art but of knowing scientifically what art is." 42 As I read him, Hegel is saying that art no longer unlocks in us the deepest secrets of the human mind in an immediate experience, because our 
attitude to art has become intellectualised. Instead of surrendering to the experience, we judge art aesthetically. Our response to art has become in a way philosophical.

On no reasonable reading is Hegel saying that art would have turned into its own philosophy, an idea cropping up in the manifestos of conceptual art in particular. From the Hegelian point of view, art could become any kind of philosophy only by ceasing to be art. The theorists of conceptual art - and, it seems, Danto as well - want to have their cake and eat it. Hegel does suggest that art had become overly intellectual and self-conscious, but that does not make it philosophy. Hegel says in no uncertain terms that art "has still a limit in itself and therefore passes over into higher forms of consciousness" and so "art counts no longer as the highest mode in which truth fashions an existence for itself." ${ }^{\prime 3}$ And those higher forms of consciousness that come after art are not art reborn but religion and philosophy.

For all his dismissal of Hegel's metaphysics as bizarre, Danto in effect accepts the main elements of Hegel's theory, but interprets them in a manner that is alien to Hegel. Danto maintains that art has an end in the sense of a goal in its destiny to become philosophy. As I have pointed out, Hegel's view was that art was by its very nature destined not to turn into philosophy but to give way to philosophy. ${ }^{44}$ It seems to me that the best way to naturalize Hegel's metaphysics is not revamp the history of the Spirit, but to abandon it altogether. If we abandon Hegel's metaphysics of the Spirit - as we surely have to if our aim is truth rather than historical interpretation ${ }^{45}$ - the history of art Hegel tells is a version of the traditional view of the development or realisation of certain things as trained on perfection. ${ }^{46}$ Perfection is the end in the sense of a goal. Now pursuit of perfection makes sense only if it is a particular perfection, perfection in some respect. ${ }^{47}$ For Hegel perfection of art concerns the artwork's content (Inhalt), means of presentation (Darstellungsmittel) and their mutual appropriateness or inappropriateness. ${ }^{48}$ These are very general concepts and from them alone it does not follow that there should be one unique way of perfectly matching content and presentation, or that the pursuit of perfection would be destined to lose direction and disintegrate once ideal perfection had been reached. I think there is in art something like pursuit of perfection, but the lesson of the history of art is surely that there is no unique summit of perfection for which all art strives. But then there is no end in the sense of an end point of development inherent in art either. Hegel's romantic admiration of classical Greek culture blinded him to the virtues of his contemporary art, which he could only see in 
terms of an impossible struggle to capture infinity (of Christian teaching) by means of the necessarily finite, sensuous means of presentation available to the artist. ${ }^{49}$

Art without ends will have a multiplicity of histories with no one unique true history among them. However, the various histories can be similar in important respects. My position is that while there are no immutable facts of art or culture that would as it were steer the hand of the historian, our need to understand and value art gives preference to certain types of history. This, it seems to me, was Hegel's enduring insight, which tends to get lost in the metaphysical extravagance. The three key elements of this conception of history are that history is (i) a process of development (ii) striving for some sort of perfection such that (iii) the process is irreversible. This substitutes for Hegel's impossible metaphysics concepts open to ordinary philosophical analysis. I shall presently embark on such an analysis, but shall first briefly look at Danto's two different views on how history is involved in the essence of art. I think Danto misinterprets Hegel, but his ideas merit consideration on their own right.

In The Transfiguration of the Commonplace, Danto argues that after Duchamp and Warhol there need not be any discernible difference between a work of art and a "mere thing," and he suggests that "[a]rt is the kind of thing that depends for its existence on theories" and to see something as art demands "an atmosphere of artistic theory, a knowledge of the history of art." ${ }^{50}$

Danto's clever illustrations, real and imaginary, raise the question whether the alleged theory-dependence is true of all art or only of what Danto later calls post-historical art, that is, Western art of the past hundred years or so. If we look at earlier art, we hardly need theory to tell works of art apart from "mere things," as there are no mere things faintly resembling any pre-2oth century work of art. Danto would naturally reply that it requires something like theory to see and in particular appreciate even Mona Lisa as a work of art. That is undoubtedly so, but the same surely holds true for many other things as well. An atmosphere of theory is needed to see, say, the moon as a secondary planet orbiting around the earth. It would be even easier to find examples from the sphere of religion. It requires an atmosphere of doctrine and history to distinguish between the same wine in a bottle and in a communion chalice..$^{51}$ This is not intended as criticism, as Danto nowhere claims that art is the only theory-dependent phenomenon, but it certainly raises the question of how art is to be distinguished from the many other theory-dependent 
phenomena. $^{52}$ In so far as the history of art is part of the atmosphere of theory, or the art world, which appears to serve the same function in some of Danto's formulations, ${ }^{53}$ it is in some sense constitutive of art, but not in any such way as would provide specific answers to my questions of how art has its history and what kind of a history it is.

Danto's late Hegel-inspired view on the history of art, stated in After the End of Art, assigns history a very specific role, but claims at the same time that history is not constitutive of (the essence of) art. Art "reveals itself through history," but is only "historically indexed" in the sense that history decides the extension of the concept, that is, what art there is in the world.$^{54}$ It is the revelatory mission of history that distinguishes Danto's view from a trivial truth. History regarded as a mere sequence of events could not be assigned such a mission. Art can have its history that way only if it is a history of a certain type. Basically, it needs to be a Hegelian kind of history as a process of development. However, the notion of an end is built into Danto's account in such a manner that if we remove the supposed end (in the two sense of the word), the whole account loses much of its appeal. If I understand him correctly, Danto is saying that the goal of the history of art is for art to come to know its own nature and when that happened, the history reached its end point. Danto appears to think that once the history of art has run its course, it loses its philosophical interest and we are left with the contingencies of history, which are no longer philosophically interesting. The revelation of history cannot be that art is, as Hegel suggests, embodied meaning, ${ }^{55}$ which, as I have pointed out, does not suffice to distinguish art from many other cultural products. It must be that art has, through its history, become aware that there are no pre-established constraints on how art can embody meaning. Art need not express divine truths, nor be beautiful, harmonious and so on. This is a very interesting way of looking at the development of European art over the past hundred years or so, but with the possible exception of that short stretch in the history of art, it surely does not remove history from the essence of art. Even if Danto's "post-historical" art were in some sense ahistorical, I fail to see how that by it itself would lift all art out of its history. ${ }^{56}$ How else could we recognise post-historical art except with reference to historical art, and that is surely a matter of an internal relation. I think Danto misses Hegel's key insight that all historical understanding, including that of history itself, essentially has a history. For my part, I fully subscribe to the Hegelian view that what we now consider a commonplace view of history is historically derived. 


\section{History of art as history of development}

All earliest histories, including histories of art, are records or chronicles, chronological accounts of events, actions, objects, whatever. In its simplest form a chronicle organises its contents through the external relation of temporal succession - B succeeds A, C succeeds B, and so on. We are not satisfied with mere chronicles because we expect from history insights into why and how something came about. ${ }^{57}$ This requires that the elements of a history be related in addition to temporal succession, by other types of external and internal relations. In the history of art $\mathrm{B}$ can be caused by A, C can be consciously influenced by B, D can be a variation of $\mathrm{C}, \mathrm{E}$ can be intended as a tragedy and thereby refers to certain other works and so on. The connections can then constitute parallels, contrasts, continuities, transitions, variations, ruptures, erasures and so on. Establishing such connections puts an interpretation on the elements of the history. The idea of development is in some measure inherent in this way of looking at history, but certainly not in a specifically Hegelian sense. There need not be any one overriding line of development and development as such requires no teleology of ends (in the two senses of the word). A line or process of development may just come to an end without reaching some preconceived end. Indeed, the very idea of history having preconceived ends makes sense only if we say, in a Kantian spirit, that we put those ends into the history in order to make sense of whatever the history is about. ${ }^{58}$ It makes no essential difference that, as Hegel in his complex manner says, we are here dealing with history essentially dependent on human intentions, actions and their products. It does not follow from the fact that the actors of a history act intentionally that they are motivated by a common preconceived goal.

The idea that art would have its history as a process of development is virtually empty unless it is said in regard of what art is supposed to develop. Hegel understood this well and gave content to (made concrete, as Hegel himself would have said) the extravagant philosophical development history of the Spirit through a development history of "art forms" (Kunstformen). For Hegel historical development was intelligible only if it was trained on perfection. Hegel-inspired art history in a way naturalized Hegel by replacing the notion of art form as manifestation of the Spirit with the cultural concept of style. To be sure, the idea of progress lingered and perhaps still lingers in the histories told by art historians, but the concept of style as such entails no Hegelian ascension, let alone one with an end point. Indeed the development of style became the main problem to be solved in art history. ${ }^{59}$ It seems to me that the answer to 
the question of how art has its history can only be that art has its history by way of a certain type of history, and I see no serious alternative to it being in a general way a history of development. This is the general answer to the two questions I raised above (p. 54).

I have made a start on describing development in very general and non-teleological terms and thereby taking distance to the Hegelian view of progress that has had such a powerful influence on our thinking about human history in all its reaches. The art historians naturalized Hegel in substituting human mind for the Spirit. Still their histories have a flavour of inevitability. Wölfflin for instance sketches a rather grandiose internal history of art as history of the human vision, or the imaginative faculty. He suggests that history can be captured in art by means of five pairs of contrastive, internal stylistic concepts, such as linear-painterly and tactile-visual.

The details of Wölfflin's scheme are not important here, but he has two interesting ideas about the history of art as a whole. First of all, he thinks development, along the axes of his contrastive concepts, say from the linear to the painterly, has some sort of internal psychological and stylistic necessity about it and therefore runs "in one direction." ${ }^{\prime 0}$ Leaving aside old-fashioned philosophical psychology, the idea is that history as a history of development is unidirectional not just in the trivial sense of temporal succession but for some internal reasons.

Wölfflin's second notable holistic idea is that the history of art consists in repeated development from what he calls classic art to baroque art. However, the development is not cyclical, but spiral, with every point of "recommencement" marking some sort of regeneration. Instead of thinking of the spirals of development constituting, in a Hegelian way, a continuous totality of history, we could simply regard them as self-contained stretches of historical development. More generally, as there is no reason to believe that the development of art would be governed by any universal laws of development of the kind proposed by Wölfflin and other Hegelian historians of art, we can say that the history of art can be told in innumerable more or less self-contained histories of development. What Wölfflin proposes as (universal) laws of development can best be regarded as aspects with respect to which development is traced. ${ }^{61}$

We now have three defining characteristics of histories of development. Such histories are (a) unidirectional, (b) irreversible and (c) trace development under some aspect(s) of development. To remove any idea of superhuman agencies operating in art and its history, we need an additional condition stating that the relevant aspect(s) of development be 
such that (d) bringing about changes with regard to such aspect(s) is under the artist's control. I think Hegel would not have objected to this condition. However much the history of art may be history of the Spirit, it is the intentional activity of the artists that brings art into the world.

I believe these four characteristics together essentially constitute the continuity and unity of histories of development. They distinguish such histories from mere chronologies. With this conception of history in hand we can lay to rest Hegel's and Danto's ideas of the end of history (in the two senses of the word), the idea that there is some one true history of art, but also Wollheim's claim that histories told in terms of what he calls concepts of general style lack explanatory value. To be sure, there is much going under the name of history that lacks explanatory value, but the reason is not that the histories are told by means of some general style concepts, but that they lack a proper aspect or aspects of development. Period histories dividing time into centuries or decades generally lack explanatory value, because no unit of time is as such an aspect of development.

There are no hard facts in either in the minds of the artists, or in their works, or in their contemporary cultural environment that would determine under which aspect(s) of development a history must be told. But that does not entail that the choice of the aspect(s) is arbitrary and reflects "contemporary concerns" only. It is in the competence of the historian to discover which aspects of development can best enable us to understand why art has developed the way it has. We can talk of discovery rather than invention or fancy because histories are open to criticism and even refutation.

I believe the four characteristics (a)-(d) are jointly sufficient to separate development histories from accounts of other kinds. I also believe they are at the core of the historicity of art, but before moving to that concluding issue I shall put some flesh on the bare bones of (a)-(d) by way of a few concrete illustrations and some philosophical reflections on why histories of this type essentially help us understand art.

\section{Continuity and unity of history}

If art has its history as a history of development, then art does not simply happen, but comes about through complex processes of changes that unfold under some aspect(s) of development and are, moreover, irreversible. The history of art as this kind of internal development history is unidirectional. It is tempting to think, as Hegel and Danto do, that a process that runs in one direction has an end in either of the two senses of the word, but this does by no means follow from mere unidirectionality. 
Wollheim makes an important additional point about the "historical dimension" of art, as he puts it. Art is historically considered asymmetrical with respect to its makers and its recipients. At any given time, past art is available to the audiences of art, but not in the same sense to the artists. ${ }^{62}$ And it is not just that it is not open to the artists to remake an earlier work, except by way of an ironical comment, but it is not open to her to recreate an earlier kind or style of art either. ${ }^{63}$

It is not at all obvious why the history of art should be unidirectional in this way. Instead of thinking about the matter in the abstract, it may be helpful to proceed in a Hegelian spirit and take a closer look at a particular developmental history. Ernst Gombrich has related the history of realistic pictorial representation in the West as a history of "making and matching" progressing through cumulative mastery of the means of representation at the artist's disposal. ${ }^{64}$ Then, in the same way as, say, in technology, the later would represent progress on the earlier in some respect, and going back would make no sense. I doubt that this is the right way of looking even at this particular stretch of history, and it certainly is not the right way of looking at the history of art at large. The development of art is not in a general way trained on greater technical competence and efficiency. ${ }^{65}$ However, this is only the making part of Gombrich's formula. Matching brings in the spectator. Although Gombrich stresses that matching is first and foremost a matter of learning to see reality through the picture, he maintains that the end of the development processes in the two senses of "end" is perfect pictorial illusion. It is a recurring theme in philosophical thinking about pictures and representation in general, ${ }^{66}$ but illusion as an end is nevertheless illusory in that a perfectly illusory picture would cease to be a picture for the spectator and could not be judged as a work of art.

Pursuit of greater realism in some broad sense of the slippery word could perhaps explain the unidirectionality of some stretches of the histories of some of the arts. ${ }^{67}$ But such stretches mark a very limited portion of the history of art and could not possibly give a general explanation of unidirectionality. Moreover, if we look at art in a broader historical and cultural perspective the very idea of development becomes somewhat problematic. For example Persian miniature painting has a history of schools and traditions, but perhaps no clear developmental history. To be sure, there are strands of stylistic influence and variation, but they do not necessarily add up to even stretches of irreversible, unidirectional stylistic development under some aspect(s) of development. But then there is no general reason why art should in all its reaches undergo con- 
stant development. Art can stand still and there can be interesting nonhistorical things to be said about, say, the technical mastery of the artists. However, if art stood still for good, then it would truly come to an end, as it perhaps has come in Chinese calligraphy, or came in official Soviet art. Some histories of art have an end point, but there is no reason to believe that that would be true of art in general.

The histories of art are many and varied. It can for instance happen that development under an aspect is picked up after a break. I would say that the two stretches of development constitute one discontinuous but internally irreversible history if the later stretch refers to the earlier one in a relevant sense. ${ }^{6}$ Hegel thought that art had lost its vigour in becoming overly self-conscious, but surely that is the general direction of cultural development in the big picture of Hegel's metaphysics.

Woolly Romantic notions of creativity are apt to cloud rather than elucidate the fact, for such it appears to be, that art is essentially an arena of internal development. For all its shortcomings, Hegel's insight on this point was hard-won. Hegel clearly thought that whatever parallels there may be between the aspects of development that give content to the internal history and the external circumstances of time, place and culture are contingent and only belong to the external history of art. The idea that there should be a regular and systematic connection between the internal development of a given stretch of art and contemporary Zeitgeist is doomed to be circular. This is foremost evinced in the Hegel-inspired idea of the "periodicity of the (internal) development of art" that crops up early in the history of art history. ${ }^{69}$ Romantic art, say, is Romantic because it was created in the Romantic era, and one signal feature of the era is that it gave rise to such art. ${ }^{70}$ Such double-entry bookkeeping unduly narrows down the space for historical discovery and, moreover, offers no new explanation for the irreversibility of history.

We have seen that Hegel thought about human history in its various fields, including art, as a history of the growing self-consciousness of the Spirit. Naturalising Hegel, we could conjecture that, as a matter of empirical fact, cultural development leads, as Bernard Williams suggests, towards increasingly reflective and reflexive consciousness of a shared past among people living under a given culture. According to Williams,

This consciousness itself has become more reflexive and complex in the course of human development, above all with the introduction of literacy. All human beings live under culture; many live with an idea of their collective past; some live with the idea of such an idea. ${ }^{71}$ 
In identifying certain systematic variations in cultural activities and their products as traditions and styles we are, according to Williams, attributing to the people involved complex intentions which are, moreover, self-referential in the sense that "the intentions refer to the tradition, and at the same time it is the existence of such intentions that constitutes the tradition." ${ }^{72}$ Spelled out for art, this means that the history of art is irreversible because it is part of increasingly reflexive and complex thinking about shared cultural past. ${ }^{73}$ This suggests, correctly I think, that it is not reasonable to talk about art in a culture unless we can attribute to that culture some sort of consciousness of past time, historical or mythical. Therefore, it is very difficult, if not impossible to decide whether, say, rock and cave paintings are art. The paintings hint at stylistic traditions, but the evidence is so scanty and discontinuous that we can only guess at the sort of intentions that may have been involved in the production and reception of the paintings. ${ }^{74}$

My suggestion that the idea that the many histories of art - and the arts $^{75}$ - constitute internal development histories receives support and substance from Williams' reflections and in particular from the valuable insight that consciousness of a shared past is at the heart of culture. It is the job of the historian to trace the complex and reflexive intentions constitutive of the traditions and styles. The question for the philosopher of art is how understanding the historicity of art, in the sort of general manner that I have been developing, figures in understanding what art is. It is a large question and I shall confine myself to a few analytical remarks by way of summing up the view that I have been developing here.

\section{Historicity of art summed up}

I have claimed all along that art is essentially historical. Danto praises Hegel for grasping the complexities of art, "since unlike most philosophers he had an historical rather than externalist view of the subject." I fully subscribe to that, but have opposed Danto's interpretation of Hegel that makes history a mere ladder revealing, at its end, the ahistorical, timeless essence of art. Whatever such an essence may be, it cannot, as I see it, be grasped in a Hegelian way past the historical particularity of the works, or instances of art.

I have argued that it essentially belongs to art that it has its history (or rather, histories) as a certain type of developmental history that is (a) internally unidirectional, (b) irreversible, and (c) traces change under some changeable aspect(s) such that (d) the aspect(s) is (are) under the artist's control. I suggest, then, that something, $w$, is art only if 
(i) $\quad w$ belongs to a history, $h$, that satisfies the above condition (a)-(d),

(ii) and $w$ needs to be understood and appreciated in the light of $h$.

In this formulation the variable $h$ rangers over particular histories that satisfy conditions (a)-(d). It places no other constraint on what can be a history of art.

As long as the history is internal, that is, its elements are internally related under some aspect of development, we as philosophers of art can trust the historian to take care of the discovery of such connections and the construction of a history out of them.

As far as essence is concerned, the import of (i) and (ii) is that the essence of art is neither (purely) ahistorical, as Danto appears to claim, nor historically relative, as the historicists claim. ${ }^{77}$ I fully appreciate that the two conditions turn on the normative presupposition that there are right and wrong ways of understanding works of art. No adequate defence of it is possible here, but whatever out-and-out relativists may say, it seems to me incontrovertible that art focuses on intentional activity, and it is fundamentally wrong to hold that human actions and their results can be ascribed to and interpreted in light of whatever intentions one fancies. ${ }^{78}$

I propose (i) and (ii) as necessary conditions for something being (an instance of) art. I am by no means claiming that these conditions exhaust the necessary condition of art as we know it. I see no objections to for instance Danto's conditions of aboutness and embodiment, as long as they are not asserted as a way of lifting art out of its history, which in my view Danto is doing. It would be only too easy to invent counterexamples to show that (i) and (ii) are not sufficient conditions. The same holds for Danto's proposed definition and indeed any definition of art I can think of. I also think Hegel and Williams have the explanation for this insufficiency. As a historical and cultural activity art becomes increasingly self-conscious and reflexive in a way that is essentially involved in the making and understanding of art. If that is so, it will not be possible to distinguish art from other cultural activities and their products without certain reference to art itself. As I see it, this circularity is not vitiating as such..$^{79}$ On the contrary, it seems to me that it makes little sense to speculate about art philosophically beyond the pale of history and culture. Plato and his followers would disagree, but then I can see no way of understanding their position save historically. One limit of philosophy in this area is marked by the question of the possible biological, psychological and social origins of art. It is primarily a question for empirical research and theory, but I am by no means advocating philosophers' 
traditional complaisance towards empirical research. It is to a significant extent a conceptual, philosophical rather than purely empirical question whether a hypothesis concerning supposed pre-historical human behaviour and its products could reasonably apply to and account for art as we know it. ${ }^{80}$ As Kant put it, conception without perception is empty, and perception without conception is blind.

\section{Notes}

1. The first version of this paper was presented at the Annual Conference of the Nordic Society of Aesthetics held in Trondheim, Norway, on 11-14 June 2009. The theme of the conference was "The Future of Aesthetics."

2. Kai Nielsen defines historicism in its original sense as "the doctrine that knowledge of human affairs has an irreducibly historical character and that there can be no ahistorical perspective for an understanding of human nature and society" (Kai Nielsen, "Historicism," in The Cambridge Dictionary of Philosophy, second edition, ed. Robert Audi (Cambridge: Cambridge University Press, 1999). Herder is one of the "anti-enlightenment" originators of this type of historicism (for an illuminating analysis of the debate over the role of history in philosophy in 18th century Germany, see Karl Ameriks, Kant and the Historical Turn: Philosophy as Critical Interpretation (Oxford: Clarendon Press, 2006), here more specifically 188-190). The notion of historicism was given an entirely different meaning by Popper, who attributed to historicists the belief that there are historical laws. Popper claims that Hegel was "the source of all contemporary historicism" (K. R. Popper, The Open Society and Its Enemies, vol. 2, The High Tide of Prophecy: Hegel, Marx and the Aftermath [London: Routledge \& Kegan Paul, 1966/1947], 27), which, from the perspective of the 1940s, comprised virulent nationalism swearing in the name of historical destiny and mission on the one hand and the Marxist version on historical determinism on the other hand. Popper's conception is alien to historicism as it is now most commonly understood. There is no denying that Hegel presents history, as Popper says, as a scene on which a grand drama, written and directed by a supra-historical agent Hegel calls God, is unfolding. My position here is that Hegel can - and indeed must - be stripped of such metaphysical extravagance to gain a view of history that is not historicist in any of the senses of the slippery notion.

3. The idea of history of art implicit in Kant's brief remarks on (fine) art is briefly commented upon in notes 31, 58 and 65 below.

4. Hegel thought philosophy was the summit of all knowledge and in his usage "Wissenschaft" exclusively refers to the "science" of philosophy. Knox' choice to translate "wissenschaftlich" to "philosophical" clarifies Hegel's usage, but is in a 
questionable sense anachronistic. I prefer to translate Hegel literally as the text leaves no uncertainty as to how "science" and "scientific" are to be understood here.

5. Georg Wilhelm Friedrich Hegel, Vorlesungen über die Äesthetik, Werke 13 (Frankfurt am Main: Suhrkamp, 1970/1842a), 26; Georg Wilhelm Friedrich Hegel, Aesthetics: Lectures on Fine Art by G.W.H. Hegel, trans. T. M. Knox (Oxford: Clarendon Press, 1975), 11.

6. Ludwig Wittgenstein, Tractatus Logico-Philosophicus, trans. D. F. Pears and B. F. McGuiness (London: Routledge \& Kegan Paul, 1961/1921), 6.54.

7. In the long run, the third front on which the future of aesthetics will be decided is marked by so-called empirical aesthetics, which has lately taken a strongly evolutionary turn. However, the problem with the many and varied attempts to delineate an evolutionary prehistory of art is not only and maybe not even chiefly empirical, but conceptual. What reason do we have, apart from preconceived theory, to assume that, say, pre-historical ritual dance and rock paintings manifest some one innate "art need" (Ellen Dissanayake, Homo Aestheticus: Where Art Comes from and Why [Seattle: University of Washington Press, 1992]) or "art instinct" (Denis Dutton, The Art Instinct: Beauty, Pleasure, and Human Evolution [New York: Bloomsbury Press, 2009]) rather than being different solutions to different adaptive problems?

8. It may be possible to delimit the class of such enterprises by some such condition as that they be in some specific sense socially and culturally constituted, but as nothing that I say hangs on such demarcation, I will not go into the matter.

9. Hegel's scheme of "world history" could appear to commit him to historical determinism, but in my view it would be wrong to read him as asserting, say, that world history was, by some causally efficacious laws of the Spirit, determined to "travel from East to West" so that "Europe is absolutely the end of History" (Georg Wilhelm Friedrich Hegel, The Philosophy of History, trans. J. Sibree [New York: Dover, 1956/1830], 103). Such laws of the Spirit as there may be are not causally determinate in their effects in the arenas of history, art, religion and philosophy. It seems to me that we have to some extent to protect Hegel from himself to be able to judge the truth or otherwise of his ideas. For instance, Hegel may have wanted to show that the "German World" was fated to be the apex of history, but nothing in his actual telling of history forces us to regard this as more than a contingent fact of history. One cannot help thinking that interpreters reading the classics of philosophy too literally tend to do a disservice to the philosophers in removing their thinking into the realm of fiction, where one can countenance such beings as Hegel's Spirit, or the idea of history as a drama following some prior script. (I have argued that the same holds for any literal interpretation of Kant's theory of the aesthetic judgement; Risto Pitkänen, "Immanuel Kantin 
Arvostelukyvyn kritiikki - erään klassikon ymmärrettävyyden rajat," (Immanuel Kant's Critique of the Power of Judgment - the bound of the comprehensibility of a classic) in Aisthesis ja Poiesis, ed. Arto Haapala and Jyrki Nummi (Helsinki: Helsinki University Department of Art Studies, 2000).

10. Arthur C. Danto, The Philosophical Disenfranchisement of Art (New York: Columbia University Press, 1986), 204.

11. This is in no way to denigrate Hegel scholarship, which must be the starting point of any attempt to naturalize Hegel. What is at stake is asking the question that historical scholars seldom if ever ask: What truth is there to what Hegel (or any other philosopher) says about art, religion, history and so on? If that nonhistorical question is not asked, it is hard to see what relevance the philosopher could have to our contemporary concerns. Moreover, any literal reading of Hegel is quite defenseless against the sort of attack that Popper launched. (See note 9.)

12. Here Knox again puts his gloss on Hegel whose lecture topic was simply aesthetics. As the work was not written by Hegel but was compiled from his manuscript notes and his students' transcripts of the lectures, the explanatory gloss in the title is no great blemish. Hegel did, after all, give aesthetics the turn to art that it has by and large followed until very recently.

13. Hegel, Vorlesungen über die Äesthetik, Werke 13, 29-30; Hegel, Aesthetics: Lectures on Fine Art, 14.

14. Hegel, Vorlesungen über die Äesthetik, Werke 13, 30; Hegel, Aesthetics: Lectures on Fine Art, 14.

15. Heinrich Wölfflin, Principles of Art History: The Problem of the Development of Style in Later Art, trans. M.D. Hottinger (New York: Dover, 1950/1915), 9.

16. Connoisseurship, ability to identify and judge individual works, is at the heart of Hegel's idea of Kunstgelehrsamkeit. Bernard Berenson gave connoisseurship a bad name by making it, as Wollheim puts it, "serve the profit and self-aggrandizement of the rich." Believing that the artist's individual style is the key to the (aesthetic) meaning of her work, Wollheim regards connoisseurship "the most profound" mode of art history (Richard Wollheim, Painting as an Art [London: Thames and Hudson, 1987], 89). In my view certain connoisseurship integrally belongs to all art history, but exclusive emphasis on it cannot but chop up the history of art into disconnected stretches.

17. The idea of the spirit of the age is due to Kant's student Johann Gottfried Herder whose books on the philosophy of history preceded Hegel by a few decades. Karl Ameriks argues that philosophy took a "historical turn" after ahistoricist Kant and historicist Herder, reaching out for a non-relativist historical understanding of its own history (Ameriks' Kant and the Historical Turn includes an extensive scholarly bibliography). Ameriks suggests that a similar historical turn of critical interpretation of the history of philosophy took place within ahis- 
torical analytical philosophy towards the end of the last century. It is certainly notable that the title of the last book of Bernard Williams, one of the "historical turn" philosophers cited by Ameriks, Truth and Truthfulness, turns the tables on the reader who expects an ahistorical analysis with its subtitle An Essay on Genealogy (Bernard Williams, Truth and Truthfulness: An Essay on Genealogy [Princeton: Princeton University Press, 2002]). In a remarkably Hegelian spirit, Williams argues that to understand such notions as truth we need to construct their genealogy, that is, philosophical history. Nor is it necessarily incompatible with Hegel to require, as Williams does, that the philosophical fiction of a genealogy then be cashed in the currency of actual history.

18. According to Wölfflin, it is the job of the art historian to discover the elements of a particular Zeitgeist that explain the differences in style between individuals, periods and peoples (Wöfflin, Principles of Art History, 11). The elements are familiar from Hegel's description of universal history as a developmental history of the Spirit - people, nation, geography, climate and so on (Hegel, The Philosophy of History, 79-102).

19. Hegel, Vorlesungen über die Äesthetik, Werke 13, 30-31; Hegel, Aesthetics: Lectures on Fine Art, 15.

20. Unless one is prepared to accept the sort of purely external definition that the institutional theory offers, the concept of a work of art only makes sense if such works are thought of as instances of something that has an essence (see Risto Pitkänen, "The End of Art, the Beginning of Aesthetics," in Aesthetic Culture. Essays in honour of Yrjö Sepänmaa on his sixtieth birthday, 12 December 2005, ed. Seppo Knuuttila, Erkki Sevänen and Risto Turunen (Helsinki: Maahenki, 2005), 212-7).

21. Hegel, Vorlesungen über die Äesthetik, Werke 13, 39; Hegel, Aesthetics: Lectures on Fine Art, 21.

22. Hegel, Vorlesungen über die Äesthetik, Werke 13, 39; Hegel, Aesthetics: Lectures on Fine Art, 22.

23. I prefer "determinateness" to Knox' "precision," as it seems to me that "Bestimmtheit" here means simply that the particular has been determined (bestimmt) in all respects, which is not the same thing as precision.

24. Hegel, Vorlesungen über die Äesthetik, Werke 13, 39; Hegel, Aesthetics: Lectures on Fine Art, 22.

25. Where Kant strives to give a transcendental deduction of judgements of taste, Hegel sketches a pretty offhand "historical deduction" of the true concept of art (Hegel, Vorlesungen über die Äesthetik, Werke 13, 83-99; Hegel, Aesthetics: Lectures on Fine Art, 55-69). One remarkable thing about this deduction is that it is confined to German thinkers, which can only imply that in Hegel's view aesthetics scaled its heights in Germany reaching its summit with Hegel. 
26. Wollheim's talk of universal styles is rather confusing, as one of his examples is classicism. He presumably means that such concepts are not restricted to any one historical context, which is very different from universality in the ordinary sense of the concept applying to all art. It seems to me better to talk of cross-historical stylistic concepts, which can be applied across the history of art. The more so as such concepts have their history in the course of which they undergo changes.

27. Wollheim, Painting as an Art, 26.

28. Ibid.

29. Ibid.

30. Ibid., 27.

31. In elucidating the concept of genius (creative artist) Kant slips into an entirely different view, suggesting that unlike science, which is inferior to art on the point of creativity, "art somewhere comes to a halt, because a limit is set for it beyond which it cannot go, which presumably has also long ago been reached an cannot be extended any more" (Immanuel Kant, Kritik der Urteilskraft, second edition, Werke in zwölf Bänden, herausgegeben von Wilhelm Weischedel [Wiesbaden: Insel Verlag, 1957/1793], \$74, 185; Immanuel Kant, Critique of the Power of Judgment, trans. Paul Guyer and Eric Matthews [Cambridge: Cambridge University Press, 2000], 188.) This end-of-art view is clearly incompatible with and in no way entailed by Kant's definition of genius, as Paul Guyer well argues (Paul Guyer, Kant and the Experience of Freedom: Essays on Aesthetics and Morality [Cambridge: Cambridge University Press, 1993], 298-9). For more on the view of history suggested by Kant's theory of art, see note 62 below.

32. The idea of cognitive stock as a way of separating work and context runs through Wollheim's work. The most extensive discussion is in Wollheim, Painting as an Art, 89-96.

33. On the use of the camera obscura in 16th and 17th century painting, see Jean-Luc Delsaut, "The Camera Obscura and Painting in the Sixteenth and Seventeenth Centuries," in Vermeer Studies. Studies in the History of Art 55, Center for Advanced Studies in the Visual Arts, Symposium Papers XXXIII, ed. Ivan Gaskell and Michiel Jonker (Washington: National Gallery of Art, 1998). Melanie E. Gifford, "Painting Light: Recent Observations on Vermeer's Technique," in Vermeer Studies: Studies in the History of Art, eds. Ivan Gaskell and Michiel Jonkers (Yale University Press, 1998) gives an excellent technical analysis of Vermeer's method of painting light.

34. Wollheim, Painting as an Art, 91-2.

35. According to Wollheim, "in the present state of knowledge, it must be a matter of speculation precisely how [individual style] is stored in the mind" (ibid., 26).

36. I prefer to translate "Bestimmung" neutrally as "determination" rather than 
"vocation," as Knox does. Hegel of course thought art was one of the three forms of the absolute spirit (religion and philosophy being the other two), and absolute spirit did by its very nature strive for absolute self-consciousness, or the absolute idea, but it is essential to Hegel's thinking that there are different levels to the spirit's self-consciousness. It seems to me that the mission of art (religion and philosophy) is one and the same from the outset and in the quoted passage "(höchste) Bestimmung" refers to the highest level in the accomplishment of that mission rather than some different kind of mission.

37. Hegel, Vorlesungen über die Äesthetik, Werke 13, 25.

38. I wish to thank the anonymous reviewer of the article for querying an infelicitous formulation suggesting that art had in Hegel's opinion "run its course" long before his time. The decline of art in Romantic art, which found the task of suiting finite form to the infinite content of Christianity impossible, is of course an essential part of Hegel's conception of the historical development of art.

39. Hegel, Vorlesungen über die Äesthetik, Werke 13, 24; Hegel, Aesthetics: Lectures on Fine Art, 10.

40. Danto, The Philosophical Disenfranchisement of Art, 81.

41. The limitation of art is that it is bound up with sensuous media and cannot therefore reach the purity of thought that is philosophy's privilege. Hegel notes that this limitation is also a strength of art (and religion) in that in them "the Absolute Idea is present for non-philosophical people, creatures of feeling, perception, pictorial thinking" (Georg Wilhelm Friedrich Hegel, Introduction to the Lectures on the History of Philosophy, trans. T. M. Knox and A.V. Miller [Oxford: Clarendon Press, 1985/1820], 28). From a Hegelian point of view, Danto's view that art has turned into philosophy would also mean the end of (the history of) philosophy. Post-historical philosophy would then presumably be as free as art became after the alleged end of its history to do whatever it fancied. That would be one way of seeing some recent philosophy, but certainly not Danto's, which remains as vigorously analytical and argumentative as ever and I do not think Danto would like us to treat it in any other way. Be that as it may, in his recent book Unnatural Wonders, Danto states in no uncertain terms that art "had turned into philosophy through the 196os and into the next decade" (Arthur C. Danto, Unnatural Wonders: Essays from the Gap Between Art and Life [New York: Farar, Straus and Giroux, 2005], 14). I wish to thank Simo Säätelä for clarification of Danto's position on this issue.

42. Hegel, Vorlesungen über die Äesthetik, Werke 13, 26. I part company with Knox in translating "wieder hervorzurufen" as "calling forth anew" to make clear that, as I read him, Hegel is not saying that art no longer invites us to create new art.

43. Hegel, Vorlesungen über die Äesthetik, Werke 13, 141; Hegel, Aesthetics: Lectures on Fine Art, 102-3. 
44. I discuss this issue at some length in Pitkänen, "The End of Art, the Beginning of Aesthetics," 221-8.

45. See the remarks and the reference at the end of note 9 above.

46. One root of this idea of perfectibility is the Aristotelian idea of entelechy as the condition in which the essence of a thing is fully actualised. The idea of history as a process of realisation is pivotal to Hegel, who takes it for granted that only humans can have this kind of history because unlike "merely natural objects," we have "a real capacity for change, and that for the better - an impulse of perfectibility" (Hegel, The Philosophy of History, 54).

47. The problem with Kant's suggestion that art has "a limit is set for it" (Kant, Kritik der Urteilskraft, $\mathbb{S} 47,185$ ) is precisely that as it indicates no respect in which art would progress towards the alleged limit, the very idea of the limit is vacuous. See note 26 above.

48. Hegel, Vorlesungen über die Äesthetik, 25; Hegel, Aesthetics: Lectures on Fine Art, 11.

49. E.g. Georg Wilhelm Friedrich Hegel, Vorlesungen über die Äesthetik, Werke 14 (Frankfurt am Main: Suhrkamp, 1970/1842b), 136-41.

50.Arthur C. Danto, The Transfiguration of the Commonplace (Cambridge, Mass.: Harvard University Press, 1981), 135.

51. I lack the theological expertise on the doctrine of transubstantiation to understand the anonymous reviewer's comment that the parallel between the transformation of a mere thing to a work of art and the transformation of ordinary wine to Christ's blood in the communion chalice only makes sense to Protestants, but not to Catholics.

52. I construe and discuss at some length a counterexample to Danto's definition of art in Pitkänen, "The End of Art, the Beginning of Aesthetics," 231-7.

53. In the earliest formulation of his view Danto suggests that art belongs to a special world, the art world (Arthur C. Danto, "The Artworld," The Journal of Philosophy 61 (1965): 571-584). That he is using the word in a loose and metaphorical sense is confirmed by the fact that he firmly dissociates himself from the idea of the art world as an actual institutional world that serves as the basis of George Dickie's institutional theory of art (Danto, The Transfiguration of the Commonplace, viii). (George Dickie, “Defining 'Art', The American Philosophical Quarterly 6 (1969): 253-6 is the first statement of his theory.)

54. Arthur C. Danto, After the End of Art: Contemporary Art and the Pale of History (Princeton: Princeton University Press, 1997), 196.

55. Ibid., 195.

56. Pitkänen, "The End of Art, the Beginning of Aesthetics," 225-8.

57. Hegel faults "the science of art" for "only busying itself with actual works of art from the outside, arranging them into a history of art" (Hegel, Vorlesungen 
über die Äesthetik, Werke 13, 29; Hegel, Aesthetics: Lectures on Fine Art, 14). In other words, the fault of such a history is that it is an external history based on the external circumstances of art.

58. History of art is a very interesting area of history from a Kantian point of view. According to Kant, (fine) art owes its origins to (human) nature in that genius as the productive faculty of the artist "belongs to nature" (Kant, Kritik der Urteilskraft, $\mathbb{S} 46,181$; Kant, Critique of the Power of Judgment, 186). In the Critique of the Power of Judgment, his most extensive treatment of the topic of teleology, Kant stresses over and over again that we are not justified in ascribing objective ends to nature; when we talk about ends, we are talking about our subjective needs to assume ends to make sense of phenomena (e.g. Kant, Kritik der Urteilskraft, \61). As we lack a concept (rule) for the working of the artist's genius, history of art as history of genius cannot be much more than a chronology. In the one extensive study of Kant's theory of art Salim Kemal solves the problem by ignoring it and substituting Kant's general views on culture, history and moral improvement for what Kant says in the Critique of the Power of Judgement. See e.g. Salim Kemal, Kant and the Fine Art: An Essay on Kant and the Philosophy of Fine Art and Culture (Oxford: Clarendon Press, 1986), 79-84.

59. The subtitle of Wölfflin's classical treatise is The Problem of the Development of Style in Later Art.

6o. Wölfflin, Principles of Art History, 227.

61. While admitting that there is no a priori reason to assume that the concepts he employs to analyse the alleged cycles of development in "later art," that is, art on its way from the classical to the baroque, apply to all art at all times, Wölfflin suggests they could well prove universal (Wölfflin, Principles of Art History, Preface to the sixth edition, viii).

62. Richard Wollheim, "On the question 'Why Painting is an Art'," in Proceedings of the 8th International Wittgenstein Symposium, Part 1, ed. Rudolf Haller (Vienna: Hölder-Pichler-Temsky, 1984), 102-4.

Wollheim talks about painting only, but by talking about painting as an art he certainly implies that similar accounts focusing on thematisation, intentions of the artist and her medium could be given for other arts. Wollheim talks of general aesthetics and "substantive aesthetics" for the different arts (Wollheim, Painting as an Art, 8). It is a remarkably Hegelian view of the scope of aesthetics.

63. For discussion of this point, see Pitkänen, "The End of Art, the Beginning of Aesthetics," 211.

64. E. H. Gombrich, Art and Illusion: A Study in the Psychology of Pictorial Representation (London: Phaidon, 1960).

65 . The same goes for the idea that history of art is unidirectional and irreversible because it is a history of innovation and artistic revolution. Paul Guyer argues 
that there is an unresolved tension in the view of the history of art implicit in Kant's brief remarks on (fine) art. According to Kant, as a product of genius (creative artist) a work of fine art must at the same time be original and exemplary, that is, model to other artists. The requirement of exemplarity is designed to curb excessive originality in ruling out "original nonsense" (Kant, Kritik der Urteilskraft, $\mathbb{4} 4$ B 182). Guyer suggests that exemplarity evokes a stable canon of classics, while originality points to a history of continuous artistic revolution (Guyer, Kant and the Experience of Freedom: Essays on Aesthetics and Morality, 291-303). Looked at in a more neutral way, Kant's two requirements for art provide for a curious mix of external and internal history. The originality of a work can only be judged against earlier art, but that is an external relation. Exemplarity could be an internal relation, with the example of an artist serving others "as a standard or rule for judging" (Kant, Kritik der Urteilskraft, $\mathbb{4} 46,182$; Kant, Critique of the Power of Judgment, 187). This presumably means that the example of an earlier artist serves a later artist as a standard for judging the workings of his own genius, ruling out "original nonsense." (For discussion of "original nonsense," see Peter Lewis, “Original Nonsense': Art and Genius in Kant's Aesthetics," in Kant and His Influence, ed. George MacDonald and Tony McWalter [Bristol: Thoemmes, 1990].) Kant's elaboration of exemplarity gives the concept much more content. According to Kant, the ideas of the master "arouse similar ideas in his apprentice if nature has equipped him with a similar proportion of mental powers" (Kant, Kritik der Urteilskraft, $\mathbb{4} 47,185 ;$ Kant, Critique of the Power of Judgment, 188). One could see in this the rudiments of an internal history of art as history of influence. Kant thinks it is a mystery (of human nature presumably) how such influence comes about. If I understand him correctly, Kant is saying that influence is not a matter of copying, but something that takes place first and foremost in the mind of the apprentice whom the master's work serves as "a model not for copying but for imitation." The word "imitation" (Nachahmung) is confusing, but it seems to me that it essentially refers to the mind of the artist, while copying (Nachmachung) refers to the artist's work (as activity and its outcome). A philosophical analysis of the concept of artistic influence would be a worthwhile enterprise and could not overlook Kant.

66. According to a tradition reported by Pliny the Elder, a competition for pictorial illusion was staged some 2500 years ago between the Greek painters Zeuxis and Parrhasius. Zeuxis' painting of grapes lured birds to peck at them, but Parrhasius won the contest since his painting of a curtain induced Zeuxis to ask that the curtain be pulled aside. Zeuxis only fooled a dumb animal, while Parrhasius fooled a rational animal.

67. It is hard to see how music for instance could be fitted into such a development history. 
68. However, continuity is not established by all referring back. Postmodernist carnivalisation of Socialist Realism certainly refers back to what it carnivalises, but is in no sense a continuation of the history of Socialist Realism, as its aspect(s) of development is (are) entirely different.

69. Wölfflin refers the idea of the periodicity of development to the history of architecture, as shaped by Burckhardt and Dehio, and regards it as self-evident that the history of "representative art" coincides with that of architecture in its periodicity (Wölfflin, Principles of Art History, 232).

70. The grip of this way of thinking about history remains firm. Not so long ago we were told that the world had moved from the modern into the postmodern era lock, stock and barrel.

71. Bernard Williams, "Making Sense of Humanity," in Making Sense of Humanity and Other Philosophical Papers (Cambridge: Cambridge University Press, 1993), 8o.

72. Ibid.

73. On more Hegelian lines, Danto suggests that art cannot go back because art is always bound up with some way of life and there is no going back to an earlier way of life because we "cannot undo the history of mind, which has brought us to our present situation" (Danto, After the End of Art, 2-3). I take Danto to be talking about a collective history of mind, that is, of a cultural history. It is not immediately obvious why such a history should as such be unidirectional.

74. According to eminent rock paintings specialist David Lewis-Williams, rock paintings were produced in shamanistic cultures as vehicles or props for access to a spirit world (David Lewis-Williams, The Mind in the Cave: Consciousness and the Origins of Art [London: Thames \& Hudson, 2002]). I would take issue with his claim that rock paintings mark the origins of art. They could at the very best mark the origins of picture making, and in view of the evident skill displayed, the surviving paintings could not possibly be the first pictures produced by Homo sapiens. The talk about the origins of art is confusing because I can see no reason to assume that there should be a common (evolutionary) explanation for why our ancestors became story-tellers, picture-makers, music-makers and so on.

75. The real histories of art are histories of the different arts, but I can see no general reason why any of those histories would not comply with what I have been saying about the history of art in general.

\section{Danto, After the End of Art, 194.}

77. In my view Danto pays too high a price for his essentialism. The alleged ahistorical essence says next to nothing about any given individual work of art, giving free rein to historicism in their interpretation. Wollheim, for his part, takes art entirely out of history, leaving us with no explanation for its internal development either. 
Art and its History

78. One reason for the tension inherent in Kant's theory of art (see note 62 above) is that he thinks we could understand the work of the artist and its product intentionally only if we could supply a determinate concept under which they would be intentional. This then leads to a rather schizophrenic division of the artist's work into unaccountable invention (of aesthetic ideas) and intentional crafting of the invention (Kant, Kritik der Urteilskraft, $\int 48$ ).

79. I would not wish to fault, say, Dickie's institutional theory or Jerrold Levinson's historical definition of art (Jerrold Levinson, "Defining Art Historically," British Journal of Aesthetics 19 (1979): 232-250) in this connection for their more or less open circularity. As far as the history of art is concerned, the common fault of these theories is that they do not provide for the right kind of internal history of art.

8o. See note 7 above. Steven Mithen draws on an admirably broad range of empirical research in his recent account of the origins of music. Instead of speculating about the origins of art in the abstract, Mithen sketches a history of how our ancestors began to sing and dance (Steven Mithen, The Singing Neanderdals: The Origins of Music, Language, Mind, and Body (Cambridge, Mass: Harvard University Press, 2006)).

\section{Literature}

Ameriks, Karl. Kant and the Historical Turn: Philosophy as Critical Interpretation. Oxford: Clarendon Press, 2006.

Danto, Arthur C. After the End of Art: Contemporary Art and the Pale of History. Princeton: Princeton University Press, 1997.

Danto, Arthur C. "The Artworld." The Journal of Philosophy 61 (1965): 571-584.

Danto, Arthur C. The Transfiguration of the Commonplace. Cambridge, Mass.: Harvard University Press, 1981.

Danto, Arthur C. The Philosophical Disenfranchisement of Art. New York: Columbia University Press, 1986.

Danto, Arthur C. Unnatural Wonders: Essays from the Gap Between Art and Life. New York: Farar, Straus and Giroux, 2005.

Delsaut, Jean-Luc. "The Camera Obscura and Painting in the Sixteenth and Seventeenth Centuries." In Vermeer Studies. Studies in the History of Art 55, Center for Advanced Studies in the Visual Arts, Symposium Papers XXXIII. Edited by Ivan Gaskell and Michiel Jonker. Washington: National Gallery of Art, 1998.

Dickie, George. "Defining 'Art'." The American Philosophical Quarterly 6 (1969): 253-6.

Dissanayake, Ellen. Homo Aestheticus: Where Art Comes from and Why. Seattle: University of Washington Press, 1992. 
Dutton, Denis. The Art Instinct: Beauty, Pleasure, and Human Evolution. New York: Bloomsbury Press, 2009.

Gifford, Melanie E. "Painting Light: Recent Observations on Vermeer's Technique." In Vermeer Studies. Studies in the History of Art. Edited by Ivan Gaskell and Michiel Jonkers. Yale University Press, 1998.

Gombrich, E. H. Art and Illusion: A Study in the Psychology of Pictorial Representation. London: Phaidon, 1960.

Guyer, Paul. Kant and the Experience of Freedom: Essays on Aesthetics and Morality. Cambridge: Cambridge University Press, 1993.

Hegel, Georg Wilhelm Friedrich. Aesthetics: Lectures on Fine Art by G.W.H. Hegel. Translated by T. M. Knox. Oxford: Clarendon Press, 1975.

Hegel, Georg Wilhelm Friedrich. Introduction to the Lectures on the History of Philosophy. Translated by T. M. Knox and A.V. Miller. Oxford: Clarendon Press, 1985/1820.

Hegel, Georg Wilhelm Friedrich. The Philosophy of History. Translated by J. Sibree. New York: Dover, 1956/1830.

Hegel, Georg Wilhelm Friedrich. Vorlesungen über die Äesthetik. Werke 13. Frankfurt am Main: Suhrkamp, 1970/1842a .

Hegel, Georg Wilhelm Friedrich. Vorlesungen über die Äesthetik. Werke 14. Frankfurt am Main: Suhrkamp, 1970/1842b.

Kant, Immanuel. Critique of the Power of Judgment. Translated by Paul Guyer and Eric Matthews. Cambridge: Cambridge University Press, 2000.

Kant, Immanuel. Kritik der Urteilskraft. Second edition. Werke in zwölf Bänden, herausgegeben von Wilhelm Weischedel. Wiesbaden: Insel Verlag, 1957/1793.

Kemal, Salim. Kant and the Fine Art. An Essay on Kant and the Philosophy of Fine Art and Culture. Oxford: Clarendon Press, 1986.

Levinson, Jerrold. "Defining Art Historically." British Journal of Aesthetics 19 (1979): 232-250.

Lewis, Peter. “'Original Nonsense': Art and Genius in Kant's Aesthetics." In Kant and His Influence. Edited by George MacDonald and Tony McWalter. Bristol: Thoemmes, 1990.

Lewis-Williams, David. The Mind in the Cave: Consciousness and the Origins of Art. London: Thames \& Hudson, 2002.

Mithen, Steven. The Singing Neanderdals: The Origins of Music, Language, Mind, and Body. Cambridge, Mass: Harvard University Press, 2006.

Nielsen, Kai. "Historicism." In The Cambridge Dictionary of Philosophy. Second edition. Edited by Robert Audi. Cambridge: Cambridge University Press, 1999.

Pitkänen, Risto. "Immanuel Kantin Arvostelukyvyn kritiikki - erään klassikon ymmärrettävyyden rajat." (Immanuel Kant's Critique of the Power of Judgment 
Art and its History

- the bound of the comprehensibility of a classic.) In Aisthesis ja Poiesis. Edited by Arto Haapala and Jyrki Nummi. Helsinki: Helsinki University Department of Art Studies, 2000.

Pitkänen, Risto. "The End of Art, the Beginning of Aesthetics." In Aesthetic Culture. Essays in honour of Yrjö Sepänmaa on his sixtieth birthday, 12 December 2005. Edited by Seppo Knuuttila, Erkki Sevänen and Risto Turunen. Helsinki: Maahenki, 2005.

Popper, K. R. The Open Society and Its Enemies. Vol. 2, The High Tide of Prophecy: Hegel, Marx and the Aftermath. London: Routledge \& Kegan Paul, 1966/1947.

Williams, Bernard. "Making Sense of Humanity." In Making Sense of Humanity and Other Philosophical Papers. Cambridge: Cambridge University Press, 1993.

Williams, Bernard. Truth and Truthfulness: An Essay on Genealogy. Princeton: Princeton University Press, 2002.

Wittgenstein, Ludwig. Tractatus Logico-Philosophicus. Translated by D. F. Pears and B. F. McGuiness. London: Routledge \& Kegan Paul, 1921/1961.

Wölfflin, Heinrich. Principles of Art History: The Problem of the Development of Style in Later Art. Translated by M.D. Hottinger. New York: Dover, 1950/1915.

Wollheim, Richard. "On the question 'Why Painting is an Art'." In Proceedings of the 8th International Wittgenstein Symposium. Part 1. Edited by Rudolf Haller. Vienna: Hölder-Pichler-Temsky, 1984.

Wollheim, Richard. Painting as an Art. London: Thames and Hudson, 1987. 